\title{
Politeness Strategies in EFL Classroom Context: Avoiding Future Conflict and Maintain the Harmony of Diversity
}

\author{
Elita M. Sembiring ${ }^{1} \&$ Srisofian Sianturi ${ }^{2}$ \\ ${ }^{1}$ Universitas Methodist Indonesia, Medan. Indonesia \\ ${ }^{2}$ Universitas HKBP Nomensen, Medan. Indonesia \\ elitamodesta@gmail.com
}

\begin{abstract}
Received : 2019-07-18
Revised : 2019-08-08

Accepted : 2019-10-28
\end{abstract}

ARTICLE HISTORY

\section{KEYWORDS}

\section{Politeness}

Politeness Strategies

Communication

Cross Cultural Understanding Class

\begin{abstract}
The research aims to investigate the politeness in language and action by students of Letters Faculty at Methodist University. Seeing the students from different etnic, religion, and culture, should be understanding and well manage to avoid future conflict and maintain the harmony of diversity among them. The research was done in the fifth-semester Cross Cultural Understanding class of Letters Faculty, The Methodist University of Indonesia. The researchers used a qualitative approach by observing the activities of students and recording their utterances during responding to the point of view. The result shows that the students applied the four types of politeness strategies in responding to context of avoiding conflict and maintain the harmony. The types are bald on record strategy, positive strategy, negative strategy and off record strategy. From the four types of politeness strategies, bald on record strategy is dominantly used by students. It is due to the students have a similar position, and it seems that no distance between them. All the communications are between students to students. For a reason, saying something directly and to the point are frequently used. Being polite should be in words and actions. From the research, students are polite in words but not in action.
\end{abstract}

\section{Introduction}

Every country has a different culture; even everyone also has different personal culture. Each culture influences the way its people talking. It depends on its culture. Mazari and Derraz (2015) proposed that "Culture is a product of a language and language is the tool of expressing culture". It means when someone studies of something related to culture he/she uses language. Language and culture are interconnected each other. Language is a part of a culture and culture is a part of a language. The two are intricately interwoven so that one cannot separate the two without losing the significance of either language or culture.

The present study investigates the degree of polite and impolite can be separated from the aspect of perception and evaluation, that's diversity and irregularities, (Sharifian 2011, 2015). (Im) polite behaviour based on culture. That is why the degree of politeness is not the same in every person. It is based on his/her culture. Culture has a significant actor in politeness. Polite behavior and speech in one culture can be interpreted as impolite for another cultures. To avoid overgeneralisations towards culture which are of limited value and to avoid treating culture as normative concept, Ealen 2001; Mills \& Kadar 2011; He 2012; Garfinkel, cited in Haugh 2013, and Sharifian 2017 proposed the analytical tools of Cultural Linguistics.

Politeness and impoliteness emerges by individual in interactional context. Iim) politeness varies accros individual as every individual has personal understanding based on knowledge and experience about context (Fukushima \& Haugh 2014, Kadar \& Haugh 2013, Haugh 2013. Classroom interaction helps student to involve $\mathrm{n}$ communication. it is believed to contribute the language development on student, (Consolo, 2006). Further, EFL learner interactional context has been studied by some experts. Senowarsito (2013) explores the positive politeness strategies as the dominantly used by students and teacher in the classroom. The choice of politeness strategies is affected by social distance, the age, the students' power and the limitation of the linguistic ability. Students and teacher have shown the politeness in utterances". It strengthens that the relationship between teacher and students in the class is maintained where students and teachers recognize each of them very well. The differences between students and teachers created different ways of using the strategy of being polite. 
Similar to politeness strategies used by Iranian EFL Learners proposed by Adel (2016) identified the EFL learners of Iranian that used positive politeness strategies as the dominantly used by students and teachers in communication.

In addition, Izadi \& Zilaie (2012) collected 60 emails written by 25 male and female Iranian speakers whose relationship was friendly, and the result show that positive politeness strategies is most frequent .

These presented studies explore the politeness strategy used by EFL learners by avoiding their cultures. Different from the previous study, here, the writer presents the politeness strategy used by students with their own culture in the interaction context. Thus, the problems of this study are formulated as follows. First, how do the students in fifth-semester students describe the politeness in responding to the point of view? Then, what type of politeness strategy is used by the fifth-semester students in responding to the point of view? The last is what type of politeness strategy is dominantly used by the fifth-semester students in responding to the point of view?

\section{Literature Review}

\subsection{Politeness}

Different language and cultures will apply different ways of being polite behavior and utterances Brown and Levinson (1987). Being polite has the purpose of saving the image both of the hearer and speaker. By keeping the image both hearer and speaker, the harmonious relationships are still maintained. The model is called "Face" as Brown and Levinson (1987). The face is related to the desire of both hearer and speaker to be freed and desirable. Brown and Levinson divided the face into two. Positive face (the need to be free), and negative face (the need to be beneficial, wanted. In communication, both of the faces must be maintained to avoid the threat.

Besides, positive and negative face determines the use of ways of being polite in social interaction. The way we communicate to someone we recognize well will be different from the approaches to someone we don't recognize well. In the word, for every person, we have different ways of being polite as we are different, Meyerhoff (2011). Moreover, SpencerQatey 2008; Culpeper 2011 added, the notion of face is the most important consideration in social interaction. It has a big role in society's norm. Politeness is a norm, (Kadar \& Haught 2013). Politeness is associated with moral or norm which is applied in society. It teaches people how to behave in social life.

In additon, politeness is the rule which is set and agreed by a society then applied among people's interaction. Politeness is called "manners". When people are communicating, there are rules or manners which must be followed by people. When those are ignored, people will be called arrogant, selfish, even uncivilized (Sibarani, 2004).

\subsection{Politeness Strategies}

Politeness strategy is a way to convey the utterances as polite as possible stated by Brown and Levinson (1987). Central to their theory is the notion of face. Thus, all participants are supposed to maintain two types of the face during interaction: 'positive' face (paying attention to others' face needs) and 'negative' face (ensuring that the other is not imposed on). Thus, in the spirit of maintaining face, interactions are supposed to minimize Face Threatening Acts (FTAs) such as criticisms, disagreements and embarrassing during their interaction. Brown and Levinson also suggest that during these FTA moments, we commonly utilize an array of linguistic strategies, or 'politeness behaviors,' to mitigate or defray interpersonal conflict.

Politeness strategies by Brown and Levinson (1987) can be realized into 25 politeness strategies which are classified into two categories; they are positive and negative politeness. Positive politeness strategy is a strategy of speaking which is used a kind of metaphorical extension of intimacy to imply common ground or sharing of wants to a limited extent even between strangers who perceive themselves: for interaction. Negative Politeness Strategy is a kind of strategy where both hearer and speaker want to be free. He/she has no obstacle. He needs full intention without any rejection.

Brown and Levinson have proposed the fifteen strategies of positive politeness strategies used by people in all over the world. The strategies are: (1) regarding the condition of the hearer. It cannot be denied that people want to be noticed. For the reason, speaker should be aware of the attending of the hearer. (2) Exaggerating the feeling with hearer. Speaker should have big sympathy in looking at hearer's feeling. It should be understood to put himself/herself to get the feeling of the hearer. By exaggerating in the right time, hearer feels understood. (3) Increasing the attention to the hearer. In communication, giving interest and improving the attention of the hearer are needed. One of the way is by telling her/him a good story. Directly speech is better used than indirectly speech. (4) Using the identity marker. Speaker indirectly demand the similarity with the hearer. It can be known by including in group use of address forms, language, dialect etc. (5) Looking for the approval. Saving the topics and doing repetition are the ways indicating to this strategy. It strengthens the agreement and satisfies the hearer. (6) Preventing the conflict. This strategy is trying to save the face of the hearer. (7) Upgrading the similarity with the hearer. Speaker tries to see the interest of the hearer for a while by telling him/her the unrelated topic and tries 
to show that the speaker does not mean to create the damaging face of the hearer. (8) Joking to the hearer. (9) Emphasizing the speaker's awareness and supposing to hearer's desire. This strategy is used to interpret awareness of hearer's desires. (10) Dedicating and contributing to the hearer. Dedicating and contributing are the products of the strategy. It sometimes lies to the hearer. Even the hearers are false, the speaker demonstrates the speaker's good wants and it satisfies the hearer. (11) Being optimistic to the hearer. This strategy indicates the speaker's confidence to ask the hearer will not mind doing something. (12) Including the speakers' and the hearers' action. Including the hearer in the action of speaker is the indication of this strategy. For example, the speaker tends to use "we" which refers to "me and you, or she/he in conversation. It is done to minimize the threat, and the speaker and hearer feel respected. (13) Providing the argument. Providing the argument for hearer is used to see the agreement of the hearer. There is a reason for doing something by speaker and the hearer is led to know it reasonably. (14) Regarding the recompense. Cooperating between speaker and hearer is the indication of this strategy. Speaker and hearer should be in the deal to have recompense or exchange between speaker and hearer. (15) Providing gifts to the hearer. Providing the gifts such as goods' sympathy, understanding, and cooperation to the hearer creates the satisfaction of the hearer. Human relationship wants to be like, admired, understood, and listens. Thus, by providing the gifts, hearer will be felt understood and it will ignore the damaging of hearer's face.

Furthermore, Brown and Levinson stated the negative politeness which consists of ten strategies. The strategies are: (1) Speaking indirectly to the hearer. Saying directly to the hearer is used by the speaker to avoid misconstruction/misinterpretation of what he/she means. (2) Using the question hedge. This is used to change the enforce of the acts of the speech. (3) Being pessimistic. This strategy is used to express the hesitation. This strategy tries to reject indirectly. (4) Reducing the imposition. This strategy is used to minimize the coercion of the hearer. It shows the deference given by the speaker to hearer seriously. (5) Delivering the appreciation. This strategy is used to humiliate and insult himself in order to the coin in the realization of the respect. It satisfies hearer's want to be treated as superior. (6) Apologize. By apologizing for doing an FTA, the speaker can indicate his reluctance to impinge of H's negative face a thereby partially redress that impingement. (7) Impersonalize speaker and hearer. This strategy implies that the speaker doesn't want to invade on hearer's identity. Avoiding the pronoun "I and You're as identification of this strategy. It means that the speaker is not alone, and the hearer also, not alone. (8) State the FTA as a general rule. Speaker doesn't want to invade but is merely forced to by circumstances. This strategy does not affect the hearer to do something but is done by hearer by the case. Circumstance is for the hearer to do so. The events are the social rule, regulation or obligation. By the conditions, speaker forces hearer to do indirectly. (9) Nominalize. It shows formality which is associated with the noun end of the continuum. (10) Go on record as incurring debt, or as not indebting hearer. Speaker can redress an FTA by explicitly claiming his indebtedness to the hearer, or by disclaiming any obligation of the hearer.

Different culture perceive different ways of being polite. as politeness strategies are associated with culture. and the purpose is maintaining the face both hearer and speaker. In cultures such as in Karonese and Toba Batak cultures, the face is maintained in a different way. Politeness for Karonese is a way to express the deference. Sembiring (2012) found that Karonese people show their respect by speaking indirectly in one of the traditional party "Cabur Bulung.". This result supported Ginting (2007) who proposed " Being polite in Karonese language expressed by using some strategies (pronouns, greetings, and indirect speech). These strategies are used to express the deference of karonese people. By expressing the deference, people of karonese are called polite.

As the scale of politeness depends on its culture, the strategies of being polite are different. For example, when speaking to someone who is very honored in Karonese culture, they tend to use indirect speech. Karonese people hardly to speak directly as it is not a diplomatic strategy. Then by using pronouns such as "we" is very polite to use. The use of these elements in communication expresses how close the relationship they have.

Different from the result detected by Sianturi (2012) that Toba Batak teenagers are speaking directly and to the point when they are communicating. This case is the way of their strategies of being polite. Saying something straight and to the end will make the hearer understand clearly rather than assuming something indirectly.

\section{Method}

This study applied a qualitative research design by describing the phenomena of language in society. Qualitative research has a natural setting as a direct source of data, and the researcher is the principal instrument. Researcher entered and spent considerable time in the location. The data were collected on the premises and supplemented by the understanding that was gained by being on site. Besides, mechanically recorded materials were reviewed in their entirety by the researcher with the researcher's insight being the critical instrument for analysis. The data of the research were taken in the form of words. It has been transcribed from the utterances uttered by the students in fifth semester. It was done in the Cross Cultural Understanding Class. After taking the data, then be 
analyzed. The analysis of the data is based on the basic concept politenes's theory proposed by Brown and Levinson (1987). It presents four types of politeness strategies, namely bald on record strategy, positive politeness strategy, negative politeness strategy, and off record strategy.

\section{Finding and Discussion}

The utterances of the students in responding to the point of view in the class are the objects of this research. Based on the research analysis, it is found that students use some politeness strategies in responding to the point of view. The students employed the four types of politeness strategies, bald on record strategy, positive politeness strategy, negative politeness strategy and off record strategy as proposed by Brown and Levinson (1987). It is similar to the way we communicate to someone we recognize well will be different from the approaches to someone we don't remember well. In the word, for every person, he/she has different ways of being polite as everyone is different, (Meyerhoff, 2011).

\subsection{Bald On Record Strategy}

This research was done to the students in the classroom. All the students have a similar position. No difference between them.

\section{(1) Student A: So Kamu orang Aceh?}

Student B: No, I live at home with my parents. I am Batakness from Aceh. In my opinion, culture shock happened to me in my boarding house in Parang ras. The people in Parang ras, all of the people are Karonese. Then, when I buy something, I say "buk," but they say, "don't say "buk" but" bik." Then they say "kam" not" $k a u$," for the "kam" is polite and "kau" is not polite.

It can be identified that student uses politeness strategy, i.e bald on record strategy. This strategy seems that the student makes the hearers feel uncomfortable when he/she is speaking. It shocks the hearer. The expression "No I live at home with my parents" indicated that student did not try to minimize the threat to the classmates' face. They felt that they are friends. They spoke directly and to the point. Thus, there is no distance between them.

Different from the strategy of being polite detected by Sembiring (2012) that Karonese people show their respect by speaking indirectly in one of the traditional party "Cabur Bulung” and Ginting (2007) in research entitled "Kesantunan dalam Acara Perkawinan 'Angantin Manuk' stated that being polite in Karo language can be expressed through the use of pronouns, greetings, and indirect speech. The use of these elements in communication shows the relationship between the speaker and the listener. From the expression above, it can be seen that this result support these two findings previously. It strengthens that Karonese uses indirect language, pronoun, and greeting in communication. It is shown by the expression "The people in Parang ras, all of the people are Karonese. Then, when I buy something, I say "buk," but they say, "dont say "buk" but" bik." Then they say "kam" not" kau," for the "kam" is polite and "kau" is not polite. "Bik" and "kam" are the example of expressing politeness by Karonese that use the pronoun in communication. Karonese tends to use "kam" which has a similar meaning to "kau" in Indonesia and "you" in English. The result supports Sembiring (2012) and Ginting (2007).

(2) Student $X$ : Should I stand Mam? I want to ask about the opinion of culture shock.

Lecturer : Enggak capek rupanya duduk! (Aren't you tired to sit!)

From these two utterances by students (1), (2), statement (1) is responding opinion by the student to their friends. The student spoke directly and to the point. It seems that the student did not respect his/her friend. It did not have any effort to minimize the threat. Different from the utterance (2), where student responded to their lecturer, it seems that student needs to ask their lecturer's agreement first even for standing or sitting. The first utterance uses bald on record strategy while the second utterance (2) uses positive politeness strategy. The students and lecturers have different social status. Thus, the politeness strategies used by them are different. From the result, it supports Meyerhoff (2011).

Different from Senowarsito (2013) and Adel (2016) that proposed teachers and students dominantly use the positive politeness strategy, this study identified that students dominantly use bald on record strategy in responding point of view. Students and their friends dominantly did the interaction in responding to opinion in the class. Thus, the relationship between the students who are similar to one another created the type of politeness strategy where students spoke directly and to the point. This strategy is called bald on record strategy.

\subsection{Positive Politeness Strategies}

(3) Student $X \quad$ : Should I stand Mam? I want to ask about the opinion of culture shock.

Lecturer : Enggak capek rupanya duduk? (Aren't you tired not to sit?)

It can be identified that student uses politeness strategy, i.e., The Use in-Group Identity Markers, Brown and Levinson (1987). It is shown by group identity marker "Mam." to call a female lecturer who was considered as a respectable person. Calling "Mam" for female lecturer indicates the students give respect and feel close to the lecturer as well. This set of data suggests that the two parties have a good emotional relationship. 
Then, the lecturer is asked by student to give an opinion even for standing or sitting. Lecturer used Joke to respond to the question. It is shown by the expression "Enggak capek rupanya duduk?. The joke is the strategy introduced by Brown and Levinson (1987), joking is one of the positive politeness strategies indicating that the interlocutors are close enough. They mutually shared background knowledge and values. The code switching engaged by lecturer noted that she was joking. The lecturer tried to minimize the student's positive face. She wanted to make the student feel comfortable and feel that they were close to each other.

Besides, this research was done in the classroom. The lecturer has power or authority in the class. It can be reflected by giving commands and instructions and making requests. The teacher's official role in the level was revealed when he/she gave commands and instructions and made requests. By this position, a lecturer is a respectable person for the students. All the activities of the students in the class need the agreement of their lecturer. It shows that students respect their lecturer. The expression "Should I stand Mam," even for standing or sitting in the class, the student needs the agreement of the lecturer. Whatever the instruction is given by lecturer, the student needs to ask first before doing it.

(4) Student A : Ok guys, I want to ask you, what is your opinion about a different culture?

Student B :Different culture, emmm.. different culture, I think different culture is we have different ways of doing something with others.

It can be identified that the student uses Jargon and Slank. It was shown by the jargon and slang language "guys." The expression "guys" reveals how close the students one another. The students know each other thus they use this strategy to call all the students in that class. This strategy seeks to minimize the threat to the hearer's positive face. It is used to make the hearer (students) feel good about himself, his interests or possessions. It shows that students know one another very well. It attempts to minimize the distance between the student as the speaker and the student as the hearer.

More than that, as it is in the classroom research and it was done when students respond to the point of view, the formal situation is happening. Not only students are there but also the lecturer as the person who has authority in the teaching and learning process. By using the expression "guys," it seems that students treat their lecturer as their friend. There is a small distance between them, but it is acceptable as long as they have a good relationship. As it is the formal situation and lecturer has significant power and authority in the class, it seems that student does not respect their lecturer but based on the video recorded, it shows that lecturer felt good and responded it by smiling to the student. They have a very close relationship. Thus the distance between them is small.

It can be identified the strategy used by the student in responding point of view is by repetition. The student repeats the question three times. It shows the student tried to answer the question, but he did not have ideas to respond. While he was trying to get the answer, he repeated the questions many times to make it sure then explain it.

(5) Student A : We have to use a paper tissue to clean it, I think.

\section{Student $B \quad$ : Yes, you are right}

It can be identified that students use Include both speaker and hearer in the activity. It is shown by "We." The speaker means you or me. He can call upon the cooperative assumptions and thereby redress face aggressive acts and tends to use 'we' form. The speaker used the word purposefully to include the hearer in the activity.

The response of the student in this utterances uses Give gifts to the hearer (goods' sympathy, understanding, cooperation). This strategy satisfied hearer's positive-face want (that speaker wants hearer's wants, to some degree) by actually satisfying some of the hearer's wants by some actions like giftgiving not only tangible gift, but human-relations wants such as the desires to be liked, admired, cared about, understood, listened to, and so on. In this strategy, the student is heard and agreed to the point of view. The student minimized the threat by agreement.

\section{(6) Student A : What is your experience?}

Student $B \quad$ : I got shocked. It is different from our culture.

It can be identified that students in responding point of view of friend use Include both speaker and hearer in the activity. It is shown by "our" this expression indicates that one student respected another student and included them in action. Culture, in this case, does not belong to one student herself/himself but belongs to all of them in the class. For saving politeness, student included all the participants (students and lecturer) in the conversation.

\section{(7) Student A : And what about you?}

Student B : Ok, thank you, different culture happened in Aceh. Different from here Medan.

It can be identified that students use Give Gift to the hearer. It is shown by the expression "thank you." It shows speaker (student) gave goods' sympathy, understanding, and cooperation. May satisfy hearer's positive-face want (that speaker wants hearer's wants, to some degree) by actually satisfying some of the hearer's wants by some actions like gift-giving not only tangible gift, but human-relations wants such as 
the desires to be liked, admired, cared about, understood, listened to, and so on.

\subsection{Negative Politeness Strategies}

(8) Student A : Sorry, can you repeat your opinion, please!

\section{Student $B \quad$ : My pleasure!}

It can be identified that students use Apologize. It is shown by the expression "sorry," in this expression speaker (student) tried to indicate his reluctance to impinge of hearer's negative face (ensuring that the other is not imposed on). By saying "sorry" does not mean the student has something wrong, but the hearer (student) needs to repeat the point of the speaker (student). The student needs to get the repetition to make clear, and the other student respected it happily.

The student used negative politeness strategy in different ways. It used to emphasize both the speaker's and the addressee's involvement in the matter was creating imperative expression. The student used modifying elements and politeness markers in his asking. The student expressed his request to his friend politely by using "please."

\subsection{Off Record Strategy}

(9) Student A : I can ask no answer. (holding hair, sitting recklessly)

Student B : Seperti biasa ( hahaha), as usual, lah

It can be identified that students use Off Record Strategy. It is shown by the effort to reject the giving point of view and want to give a question. The speaker (student) in this case tried to ignore to give his opinion and needed to provide the question. This strategy uses indirect language and removes the speaker from the potential to be imposing. This expression used indirect way of saving something which may cause a damaging face interpretation. In this utterance, the student was trying to ignore asking the question. She was going to answer not to ask actually.

The result shown in video recorded show that the FTA happened during the student gave her point of view while did some activities which damage the communication. When student gave her point of view, she was sitting recklessly, holding her hair many times while asking the question and put the position of her body looked like someone who had no energy to speak. The result shows that students are polite in words but not in action. The utterances uttered by students are polite but different from the activities she did. This result does not support Bayraktaroglu and Sifianou (2001) and Held (1999) that stated in communication, being polite must be in words and behaviours (actions). It is not enough to be polite by creating words as polite as possible, but more than that, it should show the polite behaviour. Thus, being polite should be in words and behaviours (actions).
This study detected that students are formulating words as polite as possible, unluckly they were not showing polite behaviours.

The last but not the least, Watts (2003) is under the impression that polite behavior and polite language need to be taught. In social life, such as in school and universities, students and teachers/lecturers come from different background. Culture is one of their differences. Something which is polite to one person can be perceived as impolite to others. For a reason, respectful language and behavior must be taught to know other's way of being polite. Students in schools and universities need to see the culture of others to be polite to make them able in communication (communicative competence). In short, politeness strategies should be taught to students. Thus, this result supports the theory.

\section{Conclusion}

The result of the research brings us to the end that the way students communicate in responding to the point of view used the four types of politeness strategies. They are bald on record strategy, positive politeness strategy, negative politeness strategy, and off record strategy. From the four politeness strategies used by students in responding to the point of view, bald on record strategy is dominantly used by students. It is due to the students who have a similar position, and it seems there is no distance between them. All the communications are between students to students. For a reason, saying something directly and to the point is often used by them.

Students have a different way of being polite when they were speaking to their lecturer. It can be concluded; different social status will create different ways of being polite. For students, their lecturer has power and authority; someone who is honored and listened. Thus, the ideas of being respectful to their friends are different from the ways to their lecturer.

Interaction in social life such as in the classroom, conflict happens when we do not know others way of being polite. For a reason, it is suggested that schools and universities teach students and make the result of this result as one of the lecturers in schools and universities.

At last, being polite should be in words and actions. Formulating utterances does not guarantee the communication runs well. Our efforts must follow them. Thus. it is suggested to all the readers to be polite both in words and actions.

\section{Acknowledgment}

The authors would like to give thanks to Kemenristek Dikti for funding this research. It can not be done well without its supporting. Special thank to EFL learners (the fifth semester student of Cross Cultural Understanding) who have supported us. It can not be denied that without their involments as the 
source of the data, this research is not achieved. The last but not the least, the researchers hope that this research will be useful to all of the readers.

\section{References}

Adel, S. M. R., Davoudi, M., \& Ramezanzadeh, A. (2016). A qualitative study of politeness strategies used by Iranian EFL learners in a class blog. Iranian Journal of Language Teaching Research, 4(1), 47-62.

Bayraktaroglu, A and Sifianou, M. (2001), Linguistic Politeness: the case of Greek and Turkish, USA: John Benjamins B.V

Brown, P \& Levinson, S. (1987). Politeness: Some universals in language usage. Cambridge: Cambridge University Press.

Consolo, D.A. 2006. Classroom oral Interaction in Foreign Language Lessons and Implication for Teacher development. Linguagem \& Ensino, 9 (2), 33-55

Culpeper, J. (2011). Impoliteness: Using language to cause offence (Vol. 28). Cambridge University Press.

Eelen, Gino. 2001. A Critique of Politeness Theories. Manchester: St. Jerome: 225-250. doi: $10.2307 / 798722$

Fukushima, S., \& Haugh, M. (2014). The role of emic understandings in theorizing $\mathrm{im} /$ politeness: The metapragmatics of attentiveness, empathy and anticipatory inference in Japanese and Chinese. Journal of Pragmatics, 74, 165-179.

Garfinkel, H. (1964). Studies of the routine grounds of everyday activities. Social problems, 11(3), 225250 .

Ginting, S. A. (2007). Kesantunan Dalam Upacara Perkawinan "Angantin Manuk”. Jurnal Linguistik Terapan Pascasarjana UNIMED, 4(2), 21-28.

Haugh, M. (2013). Im/politeness, social practice and the participation order. Journal of Pragmatics, 58, 52-72.

He, Y. (2012). Different generations, different face? A discursive approach to naturally occurring compliment responses in Chinese. Journal of Politeness Research: Language Behaviour Culture, 8(1), 29-51

Held, G. (1999). Submission strategies as an expression of the ideology of politeness: Reflections on the verbalisation of social power relations. Pragmatics, 9(1), 21-36.

Izadi, A., \& Zilaie, F. (2012). Politeness strategies in email exchanges in Persian. Journal of Comparative Literature and Culture, 2(1), 86-90.
Kadar, Daniel Z., and Michael Haugh. 2013. Understanding Politeness. Cambridge: Cambridge University Press. Doi: 10.1017/CBO9781139382717

Mazari, A., \& Derraz, N. (2015). Language and culture. International Journal of Humanities and Cultural Studies, 2(2), 350-359.

Meyerhoff, M. 2011. Introducing sociolinguistics (2nd Ed.). New York:

Mills, Sara, and Daniel Z. Kadar. 2001. "Politeness and Culture". In Politeness in East Asia, ed. By Daniel Z. Kadar and Sara Mills, 21-44. Cambridge: Cambridge University Press. Doi:10.1017/CBO9780511977886.004

Sembiring, E. (2012). Politeness Strategies Used in Karoness Wedding Ceremony "Cabur Bulung". Jurnal Linguistik Terapan Pascasarjana UNIMED, 7(1), 25-30.

Senowarsito, S. (2013). Politeness strategies in teacherstudent interaction in an EFL classroom context. TEFLIN Journal, 24(1), 82-96.

Sharifian, Farzad. 2011. "Cultural Conceptualisation and Language: Theoritical Frameworkand Application. Amsterdam and Philadelphia: Johnbenjamins. Doi:10.1075/clscc.1

Sharifian, Farzad. 2015. "Cultural Linguistics." In the Routledge Handbook of Language and Culture, ed. By Farzad Sharifian, 473-492. London and New York: Routledge

Sianturi, S. (2012). Politeness Strategies Used by Batak Toba Teenagers (Doctoral dissertation, UNIMED).

Spencer-Qatey, Helen. 2008. Culturally Speaking: Managing Rapport through Talk across Cultures (2nd.ed). London: Continuum.

Sibarani, R. 2004. Kesantunan bahasa. Antropolinguistik. Medan. Penerbit Poda

Watts, R. J. 2003. Politeness. Cambridge: Cambridge University Press. 